\title{
ÉTICA ORGANIZACIONAL
}

Nos últimos anos, as questões acerca da ética ganharam atenção no domínio dos negócios. M esmo aqueles que consideravam ética um tema marginal - embora nobre e valioso - na prática e na pesquisa em gestão tiveram que mudar de opinião. Desde que empresas como a Enron e a Worldcom foram manchetes pelo comportamento antiético e ilegal de seus gestores, que levaram essas empresas à fa- lência, e que oficiais de governo, órgãos regulamentadores, executivos e pesquisadores começaram a debater questões como responsabilidade social, contabilidade e governança, o tema da ética organizacional tornou-se onipresente no domínio organizacional. N esta edição, Marina O nken, Professora da Loyola University de New Orleans, indica leituras para a compreensão deste complexo tema.

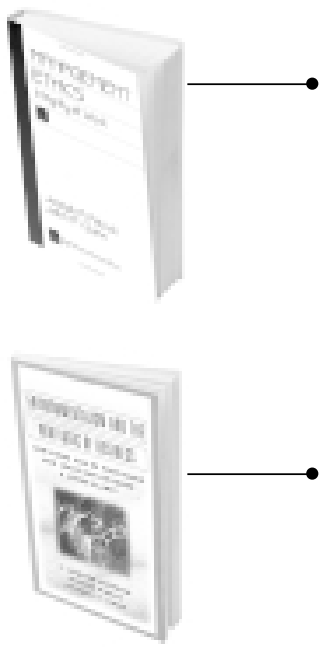

MANAGEMENTE
1997. $413 \mathrm{p}$.

Esta obra traz uma valiosa col eção de mini casos relacionados à ética nas diversas funções gerenciais. Os autores, que têm considerável experiência acadêmica e em consultoria, condizem os leitores pelas diversas perspectivas de ética, buscando estabelecer relações entre a teoria e a prática.

ENVIRONMENTALISM AND THE NEW LOGIC OF BUSINESS. R. Edward Freeman, Jessica Pierce e Richard Dodd. New York: Oxford University Press, 2000.160 p.

Este livro sustenta a idéia de que as empresas não devem apenas cumprir a lei, porém devem exceder seus parâmetros, especial mente em questões ambientais. Isso não somente guiaria os gestores para decisões mais éticas, como também mel horaria seus resultados.

RETHINKING BUSINESS ETHICS: A pragmatic approach. Sandra B. Rosenthal e Rogene A. Buchholz (eds). New York: Oxford University Press, 1999. 224 p.

A atividade empresarial é uma tarefa complexa, que relaciona-se diretamente com o ambiente político, econômico, social e tecnológico no qual a empresa se situa. Os autores exploram ética de um ponto de vista pragmático e criam um quadro de referências para a liderança moral na Administração e seu ensino.

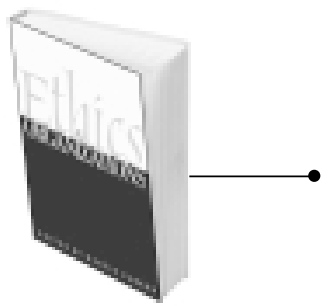

ETHICS \& ORGANIZATIONS. Martin Parker. London: Sage Publications, 1998. 308 p.

0 autor utiliza-se de uma perspectiva multidisciplinar para examinar a ética organizacional moderna e os princípios ético-morais. Trata-se de um livro val ioso tanto para acadêmicos e estudantes da área, quanto para gestores que pretendem formular um código de ética.

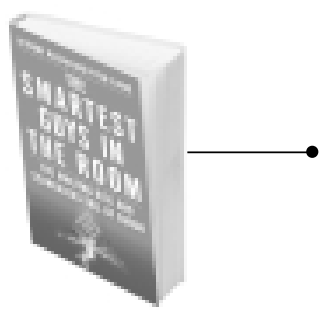

THE SMARTEST GUYS IN THE ROOM: The amazing rise and scandalous fall of Enron. Bethany McLean e Peter Elkind. New York: Portfolio, 2003. 320 p.

O livro conta a história das pessoas por trás das manchetes dos jornais. Os autores, jornal istas da Fortune, analisam os motivos e ações dos smart guys que destruiram uma das maiores empresas americanas: a Enron. 